\title{
QIYAS SEBAGAI SUMBER HUKUM ISLAM
}

\author{
Edy Muslimin
}

\author{
Institut Islam Mamba’ul 'Ulum Surakarta
}

\begin{abstract}
Abstrak: Sumber hukum Islam yang disepakati jumhur ulama adalah Al-Qur'an, Hadits, Ijma' dan Qiyas. Sedangkan sumber hukum Islam yang masih diperselisihkan di kalangan para ulama selain sumber hukum yang empat di atas adalah istihsan, maslahah mursalah, istishab, 'uruf, madzhab asShahabi, syar'u man qablana. Sebagian ulama menyebutkan enam sumber hukum yang masih diperselisihkan itu sebagai dalil hukum bukan sumber hukum, namun yang lainnya menyebutkan sebagai metode ijtihad. Qiyas sebagai salah satu sumber hukum dalam Islam maka kedudukan qiyas sebagai berikut: Pertama, Qiyas termasuk dapat dijadikan hujjah atau dalil atas hukum-hukum mengenai perbuatan manusia dan menduduki martabat atau posisi keempat diantara hujjah-hujjah syar'iyah, dengan pengertian apabila tidak didapati dalam suatu kejadian itu hukum menurut nash atau ijma'; Kedua, Qiyas merupakan suatu cara penggunaan ra'yu untuk menggali hukum syara' dalam hal-hal yang nash al-Qur'an dan sunnah tidak menetapkan hukumnya secara jelas; dan Ketiga, Tidak ada dalil atau petunjuk pasti yang menyatakan bahwa qiyas dapat dijadikan dalil syara' untuk menetapkan hukum. Juga tidak ada petunjuk yang membolehkan mujtahid menetapkan hukum syara' di luar yang ditetapkan oleh nash. Oleh karena itu terdapat perbedaan pendapat tentang kedudukan qiyas sebagai dalil hukum syara'.
\end{abstract}

Kata kunci: qiyas, sumber hukum Islam

\section{PENDAHULUAN}

Islam di tengah-tengah kemajuan segala bidang sebagai hasil dari cipta, rasa serta karya dari manusia sekarang ini di tuntut akan eksistensinya di dalam memenuhi perkembangan pengetahuan dan teknologi. Sejarah perkembangan hukum Islam telah mengajarkan kepada kita bahwa transformasi nilai sosial, kultural, ekonomi dan bahkan politik ikut mempengaruhi terjadinya perubahan hukum Islam. Hukum Islam bukanlah unifikasi yang baku yang sudah tidak bisa diinterpretasikan, melainkan sebagai kekuatan normatif yang selalu menjadikan, menempatkan, memperlakukan atau mempertimbangkan kepentingan masyarakat sebagai substansi dari posisi fleksibilitasnya (flexible-position), selama tidak berorientasi mengorbankan keluhuran hukum Islam. Oleh karena itu interpretasi terhadap perkembangan iptek serta problema umat dalam realitas sosial kemasyarakatan dalam perspektif hukum Islam merupakan keperluan yang tidak dapat ditawar-tawar lagi. ${ }^{1}$

Sumber hukum dalam Islam, ada yang Muttafaq (disepakati) para ulama dan ada yang masih mukhtalaf (diperselisihkan). Kata-kata "Sumber Hukum Islam" merupakan terjemahan dari lafazh Masadir al-Ahkam. Masadir al-Ahkam maksudnya dalil-dalil hukum syara' yang diambil (diistimbathkan) daripadanya untuk menemukan hukum. ${ }^{2}$

Adapun sumber hukum Islam yang disepakati jumhur ulama adalah Al- Qur'an, Hadits, Ijma' dan Qiyas. Sedangkan sumber hukum Islam yang masih diperselisihkan di

\footnotetext{
${ }^{1}$ www.nurulwatoni.tripod.com, 2010. Makalah Metode Qiyas Dalam Istinbat Hukum Menurut Ibnu Hazm : Pendekatan Historis. Hal. 1

${ }^{2}$ www.muhammaddarussalam.blogspot.com, 2010. Sumber Hukum Islam
} 
kalangan para ulama selain sumber hukum yang empat di atas adalah istihsan, maslahah mursalah, istishab, 'uruf, madzhab as-Shahabi, syar'u man qablana. Sebagian ulama menyebutkan enam sumber hukum yang masih diperselisihkan itu sebagai dalil hukum bukan sumber hukum, namun yang lainnya menyebutkan sebagai metode ijtihad. ${ }^{3}$

Mengenai kehujahan (alasan/dasar) masing-masing sumber hukum Islam dapat dijelaskan secara singkat dalam tulisan ini.

Pertama, menurut para ulama mazhab bahwa Al-Qur'an merupakan sumber hukum Islam yang paling pokok atau utama yang diturunkan Allah dan wajib diamalkan dan seorang mujtahid tidak dibenarkan menjadikan dalil lain sebagai hujjah sebelum membahas dan meneliti ayat-ayat al-Qur'an. Apabila hukum permasalahan yang dicari tidak ditemukan dalam al-Qur'an maka baru mencari dalil lain. ${ }^{4}$ Bukti bahwa al-Qur'an merupakan hujjah yang wajib dipedomani karena datangnya dari Allah, berpindah kepada orang (Rasulullah saw) dari Allah dengan jalan qath'i dan siapapun tidak sanggup mendatangkan yang sama dengan al-Qur'an. ${ }^{5}$

Kedua, Ali Hasabalah dalam Ushul al-Tasri' al-Islami sebagaimana dikutip oleh Nasrun Haroen mengatakan bahwa para ulama menyepakati bahwa hadits yang shahih merupakan sumber asli dari hukum-hukum syara' dan menempati posisi atau memiliki kedudukan nomor dua setelah Al-Qur'an. ${ }^{6}$ Kemudian ditegaskan bahwa Allah swt. memerintahkan supaya taat kepada Rasul, taat kepada Rasul berarti taat dan patuh kepada Allah, Dia menyuruh orang Islam apabila terjadi pertengkaran/perselisihan tentang satu masalah hendaknya dikembalikan pada Allah dan Rasul-Nya. ${ }^{7}$ Perhatikan firman Allah berikut:

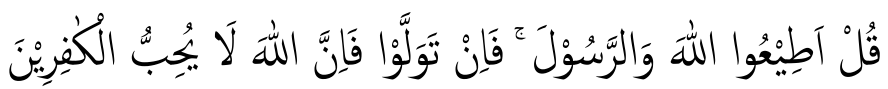

Katakanlah: "Ta'atilah Allah dan Rasul-Nya; jika kamu berpaling, Maka Sesungguhnya Allah tidak menyukai orang-orang kafir". (QS. Ali Imran: 32)

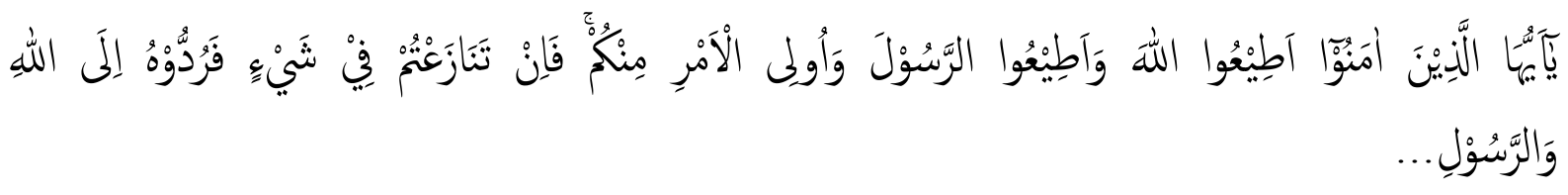

Hai orang-orang yang beriman, taatilah Allah dan taatilah Rasul (Nya), dan ulil amri di antara kamu. kemudian jika kamu berlainan Pendapat tentang sesuatu, Maka kembalikanlah ia kepada Allah (Al Quran) dan Rasul (sunnahnya)...(QS. an-Nisa: 59)

Dari ayat diatas jelaslah bahwa hadits menempati posisi kedua setelah al-Qur'an sebagai sumber hukum Islam.

Ketiga, bukti bahwa ijma dapat sebagai hujjah dan menempati urutan ketiga dijelaskan dalam QS. an-Nisa ayat 59 sebagaimana tertulis diatas "taatilah Allah dan Rasul (Nya), dan ulil amri diantara kamu”. Lafal Amri artinya ialah hal atau keadaan yang meliputi hal-hal duniawi dan agamawi. Ulil amri duniawai adalah para pemimpin sedang Ulil amri

\footnotetext{
${ }^{3}$ www.fahmirusydi.multiply.com, 2008. Sumber Hukum Islam, www.fahmirusydi.multiply.com. Hal. 1

${ }^{4}$ Nasrun Haroen, 1997. Ushul Fiqh 1, Jakarta : Logos Wacana Ilmu: hal.27

${ }^{5}$ Abdul Wahab Khallaf, 1990 Ilmu Usul Fikih, terj. Halimuddin, Jakarta : Rineka Cipta. Hal. 19

${ }^{6}$ Nasrun Haroen, Op. Cit., hal. 47

${ }^{7}$ Abdul Wahab Khallaf, Op. Cit., hal. 38
} 
agamawi yaitu para mujtahid dan ahli fatwa agama, maka apabila Ulil amri yakni para mujtahid telah mengadakan Ijma' atas suatu hukum maka wajib diikuti dan dilaksanakan hukum berdasarkan al-Qur'an. ${ }^{8}$

Keempat, Menurut jumhur ulama, qiyas termasuk hujjah syar'iyah atas hukum-hukum mengenai perbuatan manusia dan menduduki martabat atau posisi keempat diantara hujjahhujjah syar'iyah, dengan pengertian apabila tidak didapati dalam suatu kejadian itu hukum menurut nash atau ijma' tetapi terdapat kesamaan illat dengan suatu kejadian yang telah terdapat hukumnya dalam nash maka diqiyaskanlah kejadian yang pertama kepada kejadian yang kedua, jadi seorang mukallaf harus mengikuti dan mengamalkannya. Dan jumhur para ulama tersebut disebut sebagai orang yang menetapkan qiyas atau Mutsbitulqiyas. ${ }^{9}$

Dalam hal ini penulis tidak membahas secara keseluruhan dari empat sumber hukum yang disepakati para ulama tersebut tetapi pembahasannya dibatasi hanya pada satu sumber hukum saja yaitu qiyas.

\section{PEMBAHASAN}

\section{Pengertian}

Qiyas merupakan suatu cara penggunaan ra'yu untuk menggali hukum syara' dalam hal-hal yang nash al-Qur'an dan sunnah tidak menetapkan hukumnya secara jelas. Pada dasarnya ada dua macam cara penggunaan ra'yu, yaitu penggunaan ra'yu yang masih merujuk kepada nash dan penggunaan ra'yu secara bebas tanpa mengaitkannya kepada nash. Bentuk pertama secara sederhana disebut qiyas, meskipun qiyas tidak menggunakan nash secara langsung, tetapi karena merujuk kepada nash, maka dapat dikatakan bahwa qiyas juga menggunakan nash walaupun tidak secara langsung. ${ }^{10}$

Sedang mengenai definisinya menurut ulama ushul fiqh, qiyas berarti menghubungkan suatu kejadian yang tidak ada nashnya kepada kejadian lain yang ada nashnya, dalam hukum yang telah ditetapkan oleh nash karena adanya kesamaan dua kejadian itu dalam illat hukumnya (Abdul Wahab Khallaf, 2002: 74). Para ulama Hanabilah berpendapat bahwa illat merupakan suatu sifat yang berfungsi sebagai pengenal suatu hukum. Sifat pengenal dalam rumusan definisi tersebut menurut mereka sebagai suatu tanda atau indikasi keberadaan suatu hukum. Misalnya, khamer itu diharamkan karena ada sifat memabukkan yang terdapat dalam khamer. ${ }^{11}$

Mayoritas ulama Syafi'iyyah mendefinisikan qiyas dengan "Membawa (hukum) yang (belum) di ketahui kepada (hukum) yang diketahui dalam rangka menetapkan hukum bagi keduanya, atau meniadakan hukum bagi keduanya, baik hukum maupun sifat. ${ }^{12}$

Untuk dapat mengerti maksud definisi diatas maka dibawah ini penulis paparkan beberapa contoh qiyas sebagai berikut:

Jual beli diwaktu adzan haram hukumnya berdasar firman Allah:

\footnotetext{
${ }^{8}$ Op. Cit., hal. 65

${ }^{9}$ Op. Cit., hal. 77

${ }^{10}$ Amir Syarifuddin, 2009. Ushul Fiqh, Jilid 1, Jakarta: Kencana, Hal. 170

${ }^{11}$ Nasrun Haroen, Op. Cit., hal. 76-77

${ }^{12}$ www.nurulwatoni.tripod.com, Op. Cit., hal. 4
} 


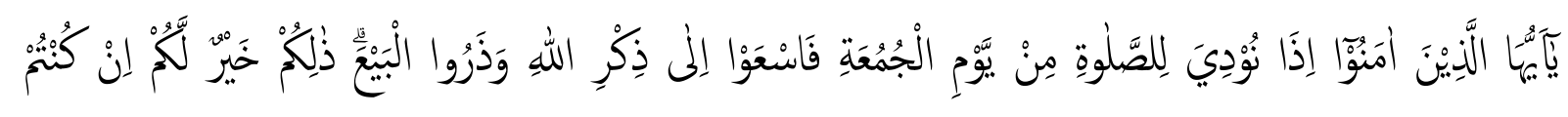

Artinya: Hai orang-orang beriman, apabila diseru untuk menunaikan shalat Jum'at, Maka bersegeralah kamu kepada mengingat Allah dan tinggalkanlah jual beli. yang demikian itu lebih baik bagimu jika kamu mengetahui.(QS. Al-Jumu'ah: 9)

Dilarang berjual beli pada waktu itu karena mengganggu sholat, maka sebab yang seperti itu termasuk pada semua macam perjanjian atau kegiatan lain yang mengganggu sholat karena disamakan dengan jual beli.

Haram meminum tuak yang dibuat dari lahang kurma, dasarnya adalah firman Allah berikut:

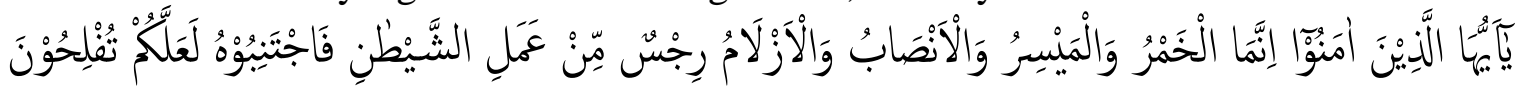

Artinya: Hai orang-orang yang beriman, Sesungguhnya (meminum) khamar, berjudi, (berkorban untuk) berhala, mengundi nasib dengan panah, adalah Termasuk perbuatan syaitan. Maka jauhilah perbuatan-perbuatan itu agar kamu mendapat keberuntungan. (QS. Al Maidah: 90).

Ayat diatas memberi penegasan bahwa haram juga meminum tuak/khamer yang dibuat dari bahan lainnya yang diqiyaskan dengan tuak kurma karena bahan lain tersebut juga dapat memabukkan. ${ }^{13}$ Hukum minuman bir atau wisky. Dari hasil pembahasan dan penelitiannya secara cermat, kedua minuman itu mengandung zat yang memabukkan, seperti zat yang ada pada khamr. Zat yang memabukkan inilah yang menjadi penyebab di haramkannya khamr. Hal ini sesuai dengan firman Allah dalam surat al-Maidah 5: 90 - 91. Dengan demikian, mujtahid tersebut telah menemukan hukum untuk bir dan wisky, yaitu sama dengan hukum khamr, karena illat keduanya adalah sama. Kesamaan illat antara kasus yang tidak ada nash-nya dengan hukum yang ada nash-nya menyebabkan adanya kesatuan hukum. ${ }^{14}$

Dengan contoh-contoh tersebut, maka jelaslah bagaimana definisi qiyas sebagai sumber hukum Islam yang disepakati para ulama karena penetapan hukum tersebut tidak menyimpang dari nash al-Qur'an.

\section{Qiyas sebagai Dalil Hukum Syara'}

Tidak ada dalil atau petunjuk pasti yang menyatakan bahwa qiyas dapat dijadikan dalil syara' untuk menetapkan hukum. Juga tidak ada petunjuk yang membolehkan mujtahid menetapkan hukum syara' di luar yang ditetapkan oleh nash. Oleh karena itu terdapat perbedaan pendapat tentang kedudukan qiyas sebagai dalil hukum syara'. ${ }^{15}$

Tentang perbedaan pendapat mengenai kedudukan qiyas, dikalangan ahli fiqih terbagi menjadi tiga kelompok seperti berikut:

Pertama, Kelompok Jumhur, yang menggunakan qiyas sebagai dasar hukum pada hal-hal yang tidak jelas nashnya dalam Qur'an, hadits, pendapat sahabat dan ijma' ulama.

74

${ }^{13}$ Syafi'i Karim, 1997. Fiqih Ushul Fiqih : Untuk Fakultas Tarbiyah, Bandung : CV. Pustaka Setia. Hal.

\footnotetext{
${ }^{14}$ www.nurulwatoni.tripod.com, Op Cit, hal. 5
}

${ }^{15}$ Amir Syarifuddin, Op Cit. hal. 177 
Kelompok ini menggunakan qiyas dengan tidak berlebihan. Kedua, kelompok Zhahiriyah dan Syiah Imamiyah, kelompok ini menolak qiyas secara penuh dan tidak mengakui illat nash, juga tidak berusaha mengetahui sasaran dan tujuan nash, termasuk mengungkap alasan-alasan guna menetapkan suatu kepastian hukum yang sesuai dengan illat. Ketiga, kelompok yang memperluas penggunaan qiyas, mereka berusaha menggabungkan dua hal yang tidak terlihat kesamaan illat diantara keduanya, bahkan menerapkan qiyas sebagai pembatas keumuman alQur'an dan hadits. ${ }^{16}$

Alasan ketiga kelompok ulama tentang penggunaan qiyas dapat dibagi lagi kedalam dua kelompok yaitu kelompok yang menerima dan menolak menggunakan qiyas, yang masing-masing mengemukakan dalil al-Qur'an, sunnah, ijma' ulama atau sahabat dan dalil akal.

Kelompok yang menerima qiyas sebagai dalil karena didasarkan firman Allah:

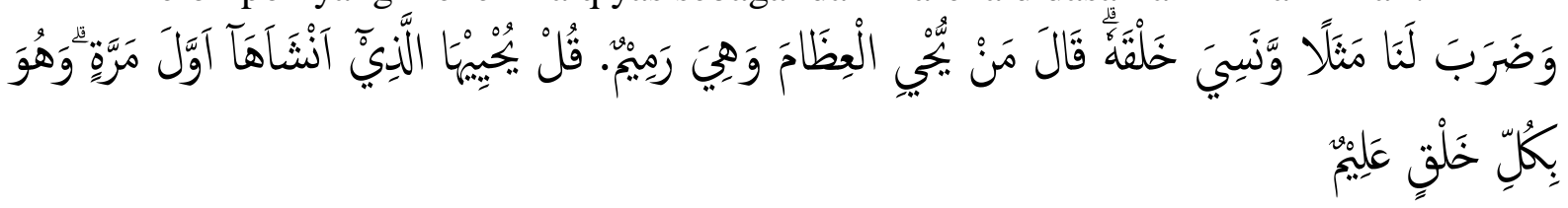

78. dan ia membuat perumpamaan bagi kami; dan Dia lupa kepada kejadiannya; ia berkata: "Siapakah yang dapat menghidupkan tulang belulang, yang telah hancur luluh?"

79. Katakanlah: "Ia akan dihidupkan oleh Tuhan yang menciptakannya kali yang pertama. dan Dia Maha mengetahui tentang segala makhluk. (QS. Yasiin: 78-79)

Ayat ini menjelaskan bahwa Allah menyamakan kemampuan-Nya menghidupkan tulang belulang yang telah berserakan di kemudian hari dengan kemampuan-Nya dalam menciptakan tulang belulang pertama kali. Artinya bahwa Allah menyamakan menghidupkan tulang tersebut kepada penciptaan pertama kali.

Dalil yang lain adalah sebagai berikut:

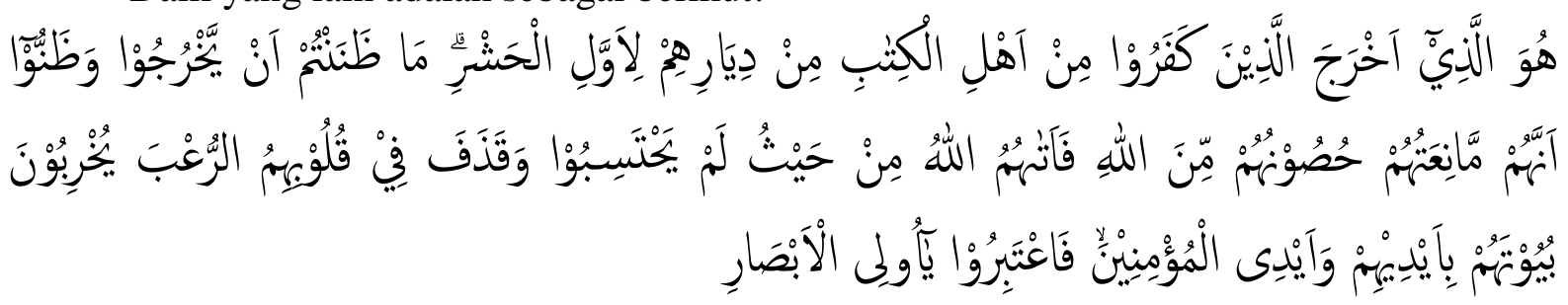

Artinya: Dia-lah yang mengeluarkan orang-orang kafir di antara ahli kitab dari kampungkampung mereka pada saat pengusiran yang pertama[1463]. kamu tidak menyangka, bahwa mereka akan keluar dan merekapun yakin, bahwa benteng-benteng mereka dapat mempertahankan mereka dari (siksa) Allah; Maka Allah mendatangkan kepada mereka (hukuman) dari arah yang tidak mereka sangka-sangka. dan Allah melemparkan ketakutan dalam hati mereka; mereka memusnahkan rumah-rumah mereka dengan tangan mereka sendiri dan tangan orang-orang mukmin. Maka ambillah (Kejadian itu) untuk menjadi pelajaran, Hai orang-orang yang mempunyai wawasan. (QS. Al-Hasyr: 2)

Jadi bila orang mukmin berbuat seperti apa yang diperbuat oleh orang kafir, akan mengalami siksaan seperti yang dialami orang kafir. Hal itu berarti: qiyas-kanlah keadaanmu

\footnotetext{
${ }^{16}$ Muhammad Abu Zahrah, 2000. Ushul Fiqih, terj. Saefullah Ma'shum dkk, Jakarta : PT Pustaka Firdaus. Hal. 339-340
} 
kepada keadaan mereka. Kelompok ulama Zhahiriyah menolak argumentasi jumhur ulama itu dengan mengatakan bahwa tidak ada peluang sedikitpun bagi qiyas dalam ayat tersebut. Tidak satupun ilmu mengenai bahasa arab sebagai bahasa al-Qur'an yang menjelaskan bahwa al-I'tibar berarti qiyas. ${ }^{17}$

Amir Syarifuddin menambahkan, kelompok ulama yang menolak penggunaan qiyas dalam hukum syara' adalah pertama, kelompok Syi'ah Imamiyah yang membatalkan beramal dengan qiyas. Mereka tidak membolehkan sama sekali penggunaan qiyas. Dalil yang populer dikalangan mereka adalah: "agama Allah tidak dapat dicapai melalui akal dan sunnah itu bila diqiyaskan akan merusak agama. Kedua, kelompok al-Nazham, mengatakan bahwa illat yang tersebut dalam nash mewajibkan adanya usaha menghubungkan hukum melalui lafaz yang umum tidak melalui qiyas. Ketiga, kelompok zhahiriyah, pandangan mereka tentang qiyas sebanarnya kelihatan dari tanggapan mereka atas argumentasi yang dikemukakan jumhur ulama. Mereka tidak menggunakan qiyas, sebagai penggantinya mereka menggunakan kaidah umum lafaz nash. Sebagai contoh jumhur ulama menetapkan haramnya memukul orang tua diqiyaskan kepada haramnya mengucap kata "uf" kepada orang tua. Ulama zhahiri tidak menggunakan meng-qiyas-kan "uf" dengan memukul orang tua namun menggunakan lafaz umum bahwa perintah Allah untuk berbuat baik kepada orang tua.

Dengan demikian dapat dijelaskan diantara keraguan mereka yang paling jelas pendapatnya bahwa qiyas didasarkan hanya pada dugaan, seperti illat hukum nash adalah begini. Dan Allah melarang mengikuti orang-orang yang megikuti dugaan, dasarnya menurut kelompok ini adalah firman Allah:

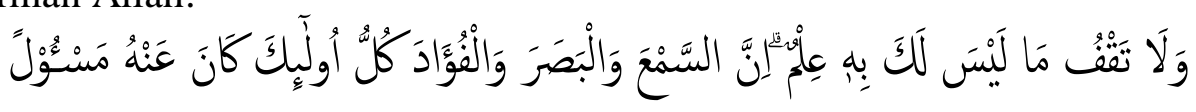

Artinya: dan janganlah kamu mengikuti apa yang kamu tidak mempunyai pengetahuan tentangnya. Sesungguhnya pendengaran, penglihatan dan hati, semuanya itu akan diminta pertanggungan jawabnya.(QS. Al-Isra: 36)

Maka tidak sah sebuah hukum yang yang berdasarkan qiyas, karena qiyas adalah mengikuti dugaan. ${ }^{18}$

\section{Rukun dan Syarat Qiyas}

\section{Rukun Qiyas}

Dari pengertian qiyas yang telah disebut diatas dapat dijelaskan bahwa unsur pokok atau rukun qiyas terdiri atas empat unsur berikut:

a. Ashl, menurut ahli ushul fiqh, merupakan obyek yang telah ditetapkan hukumnya oleh ayat al-Qur'an, hadits Rasulullah atau Ijma'. Contohnya, pengharaman wisky dengan meng-qiyas-kannya kepada khamar. Maka yang Ashl adalah khamar yang telah ditetapkan hukumnya melalui nash. Menurut ahli ushul fiqh yang dikatakan ashl itu adalah nash yang menentukan hukum, karena nash inilah yang dijadikan patokan penentuan hukum furu'. Dalam kasus wisky yang diqiyaskan pada khamar. Maka yang menjadi ashl adalah ayat 90-91 surat al-Maidah. ${ }^{19}$. Sedang Rachmat Syafe'i menjelaskan bahwa Ashl merupakan suatu peristiwa yang sudah ada nashnya yang dijadikan tempat

\footnotetext{
${ }^{17}$ Amir Syarifuddin, Op Cit. hal. 178-180

${ }^{18}$ Abdul Wahhab Khallaf, Op Cit. hal. 86

${ }^{19}$ Nasrun Haroen, Op Cit. Hal. 65
} 
meng-qiyas-kan atau maqis alaih, tempat membandingkan atau mahmul alaih, musyabbah bih atau tempat menyerupakan. ${ }^{20}$

b. Far'u (cabang), adalah sesuatu yang tidak ada nashnya menurut Muhammad Abu Zahrah seperti wisky dalam kasus diatas. ${ }^{21}$

c. Hukum Ashl, hukum syara' yang ditetapkan oleh suatu nash atau ijma' yang akan diberlakukan kepada far'u, seperti keharaman meminum khamar menurut Nasrun Haroen.

d. Illat, suatu sifat yang menjadi motif dalam menentukan hukum, dalam kasus khamar di atas illatnya adalah memabukkan ${ }^{22}$

\section{Syarat Qiyas}

Untuk dapat melakukan qiyas terhadap suatu masalah yang belum ada ketentuannya dalam al-Qur'an dan hadits harus memenuhi syarat-syarat berikut:

a. Hendaklah hukum asalnya tidak berubah-ubah atau belum dinasakhkan artinya hukum yang tetap berlaku.

b. Asal serta hukumnya sudah ada ketentuannya menurut agama artinya sudah ada menurut ketegasan al-Qur'an dan hadits.

c. Hendaklah hukum yang berlaku pada asal berlaku pula pada qiyas, artinya hukum asal itu dapat diberlakukan pada qiyas.

d. Tidak boleh hukum furu' (cabang) terdahulu dari hukum asal, karena untuk menetapkan hukum berdasarkan kepada illatnya (sebab).

e. Hendaklah sama illat yang ada pada furu' dengan illat yang ada pada asal.

f. Hukum yang ada pada furu' hendaklah sama dengan hukum yang pada asal. Artinya tidak boleh hukum furu' menyalahi hukum asal.

g. Tiap-tiap ada illat ada hukum dan tidak ada illat tidak ada hukum, artinya illat itu selalu ada.

h. Tidak boleh illat itu bertentangan menurut ketentuan-ketentuan agama, artinya tidak boleh menyalahi kitab dan sunnah. ${ }^{23}$

\section{Macam-Macam Qiyas}

Qiyas dapat dibagi menjadi beberapa segi dalam hal ini dapat dibagi tiga yaitu sebagai berikut:

1. Qiyas Awlawi, qiyas yang berlakunya hukum pada furu' lebih kuat dari pemberlakuan hukum pada ashal karena kekuatan illat pada furu'. Sebagai contoh meng-qiyas-kan keharaman memukul orang tua kepada ucapan "uf" (berkata kasar) terhadap orang tua dengan illat menyakiti. Ditegaskan Allah dalam firman-Nya:

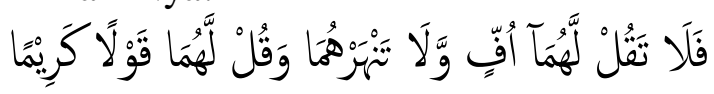

Artinya: ...Maka sekali-kali janganlah kamu mengatakan kepada keduanya Perkataan "ah" dan janganlah kamu membentak mereka dan ucapkanlah kepada mereka Perkataan yang mulia (QS. Al-Isra': 23) hal. 87

${ }^{20}$ Rachmat Syafe'i, 1999. Ilmu Ushul Fiqih untuk IAIN, STAIN, PTAIS, Bandung : CV. Pustaka Setia :

${ }^{21}$ Muhammad Abu Zahrah, Op Cit. hal. 352

${ }^{22}$ Nasrun Haroen, Op Cit. Hal. 65

${ }^{23}$ Nazar Bakry, 1996. Fiqh dan Ushul Fiqh, Jakarta : PT RajaGrafindo Persada. Hal. 48 
Keharaman pada perbuatan memukul lebih kuat daripada keharaman pada ucapan "uf", karena sifat menyakiti yang terdapat pada memukul lebih kuat dari yang terdapat pada ucapan "uf".

2. Qiyas Musawi, qiyas yang berlakunya hukum pada furu' sama keadaannya dengan berlakunya hukum pada ashal karena kekuatan illatnya sama. Umpamanya meng-qiyaskan membakar harta anak yatim kepada memakannya secara tidak pantas dalam menetapkan hukum haramnya. Firman Allah yang artinya:

"Dan berikanlah kepada anak-anak yatim (yang sudah balig) harta mereka, jangan kamu menukar yang baik dengan yang buruk dan jangan kamu Makan harta mereka bersama hartamu. Sesungguhnya tindakan-tindakan (menukar dan memakan) itu, adalah dosa yang besar."

Baik membakar harta anak yatim atau memakannya secara tidak patut adalah sama-sama merusak harta anak yatim.

3. Qiyas Adwan, qiyas yang berlakunya hukum pada furu' lebih lemah dibandingkan dengan berlakunya hukum pada ashal meskipun qiyas tersebut memenuhi persyaratan. Umpamanya meng-qiyas-kan apel kepada gandum dalam menetapkan berlakunya riba bila dipertukarkan dengan barang yang sejenis. Illatnya bahwa ia adalah makanan. Memberlakukan hukum riba pada apel lebih rendah daripada berlakunya hukum riba pada gandum karena illatnya lebih kuat. ${ }^{24}$

\section{KESIMPULAN}

Dari uraian tentang qiyas sebagai salah satu sumber hukum dalam Islam maka dapatlah penulis simpulkan bahwa:

Pertama, Qiyas termasuk dapat dijadikan hujjah atau dalil atas hukum-hukum mengenai perbuatan manusia dan menduduki martabat atau posisi keempat diantara hujjahhujjah syar'iyah, dengan pengertian apabila tidak didapati dalam suatu kejadian itu hukum menurut nash atau ijma'.

Kedua, Qiyas merupakan suatu cara penggunaan ra'yu untuk menggali hukum syara' dalam hal-hal yang nash al-Qur'an dan sunnah tidak menetapkan hukumnya secara jelas.

Ketiga, Tidak ada dalil atau petunjuk pasti yang menyatakan bahwa qiyas dapat dijadikan dalil syara' untuk menetapkan hukum. Juga tidak ada petunjuk yang membolehkan mujtahid menetapkan hukum syara' di luar yang ditetapkan oleh nash. Oleh karena itu terdapat perbedaan pendapat tentang kedudukan qiyas sebagai dalil hukum syara'.

\section{DAFTAR PUSTAKA}

Abdul Wahab Khallaf, 1990. Ilmu Usul Fikih, terj. Halimuddin, Jakarta: Rineka Cipta

Abdul Wahhab Khallaf, 2002. Kaidah-kaidah Hukum Islam: Ilmu Ushulul Fiqh, terj. Noer Iskandar al-Barsany, Moh. Tolchah Mansoer, Ed. 1., Cet. 8, Jakarta: PT RajaGrafindo Persada.

Amir Syarifuddin, 2009. Ushul Fiqh, Jilid 1, Jakarta: Kencana

\footnotetext{
${ }^{24}$ Amir Syarifuddin, Op Cit. Hal. 2
} 
250 Mamba'ul 'Ulum, Vol. 15, No. 2, Oktober 2019: 242-250

Fahmi Rusydi, 2008. Sumber Hukum Islam, www.fahmirusydi.multiply.com

Muhammad Abu Zahrah, 2000. Ushul Fiqih, terj. Saefullah Ma'shum dkk, Jakarta: PT Pustaka Firdaus

Muhammad Darussalam, 2010. Sumber Hukum Islam www.muhammaddarussalam. blogspot.com

Nasrun Haroen, 1997. Ushul Figh 1, Jakarta: Logos Wacana Ilmu

Nazar Bakry, 1996. Fiqh dan Ushul Fiqh, Jakarta: PT RajaGrafindo Persada

Rachmat Syafe'i, 1999, Ilmu Ushul Fiqih untuk IAIN, STAIN, PTAIS, Bandung: CV. Pustaka Setia

Syafi'i Karim, 1997. Fiqih Ushul Fiqih: Untuk Fakultas Tarbiyah, Bandung: CV. Pustaka Setia

www.nurulwaton.tripod.com, 2010. Makalah Metode Qiyas Dalam Istinbat Hukum Menurut Ibnu Hazm: Pendekatan Historis. 